\title{
The Impact of Lean Six Sigma Practices on Physiotherapy Services Quality at UNRWA Healthcare Centers, Gaza Strip, Palestine
}

\author{
Nabila Mohamed Abu Sharikh', Majed Mohamed El Farra ${ }^{2}$, Samer Abuzerr ${ }^{3,4^{*}}$, Khalil Madi ${ }^{5}$ \\ ${ }^{1}$ Health Department, Physiotherapy Division, UNRWA, Gaza, Palestine \\ ${ }^{2}$ Department of Business Administration, Faculty of Economics and Administrative Sciences, Islamic University, Gaza, Palestine \\ ${ }^{3}$ Department of Social and Preventive Medicine, School of Public Health, University of Montreal, Montréal, Canada \\ ${ }^{4}$ Quality Improvement and Infection Control Unit, Ministry of Health, Gaza, Palestine \\ ${ }^{5}$ Business Administration, Al-Azhar University, Gaza, Palestine \\ Email: *samer_516@hotmail.com
}

How to cite this paper: Sharikh, N.M.A., El Farra, M.M., Abuzerr, S. and Madi, K. (2019) The Impact of Lean Six Sigma Practices on Physiotherapy Services Quality at UNRWA Healthcare Centers, Gaza Strip, Palestine. Journal of Biosciences and Medicines, 7, 79-94.

https://doi.org/10.4236/jbm.2019.712008

Received: October 30, 2019

Accepted: December 1, 2019

Published: December 4, 2019

Copyright () 2019 by author(s) and Scientific Research Publishing Inc. This work is licensed under the Creative Commons Attribution International License (CC BY 4.0).

http://creativecommons.org/licenses/by/4.0/

\begin{abstract}
Integrating Lean and Six Sigma found a powerful business tool for the strategy improvement process and saving time is produced. The main aim of this study is to identify the impact of Lean Six Sigma (LSS) practices on physiotherapy service quality at healthcare centers of the United Nations Relief and Works Agency for Palestine Refugees in the Near East (UNRWA), using a descriptive-analytical approach. Data were collected using a questionnaire distributed among 49 physiotherapists working at UNRWA healthcare centers as a census sampling method between July 2016 and August 2017, following the stratified random sampling method. The Statistical Package for Social Science (SPSS) was used to analyze the collected data. The results revealed that there was a statistically significant relationship between Lean Six Sigma (LSS) dimensions and the quality of healthcare services provided in physiotherapy units at the UNRWA healthcare centers. Moreover, the application of Lean Six Sigma dimensions was adopted at $81 \%$ of UNRWA healthcare centers. Moreover, the percentage of patients' satisfaction regarding the quality of healthcare services provided in physiotherapy units was $89 \%$. The study emphasized the effectiveness of Lean Six Sigma dimensions application on the quality healthcare services provided in physiotherapy units at the UNRWA healthcare centers. Furthermore, employee training and reward according to a needs assessment to implement Lean Six Sigma successfully is highly recommended.
\end{abstract}

\section{Keywords}

Lean Six Sigma, Quality Service, UNRWA Healthcare Center, Physiotherapy 


\section{Introduction}

Nowadays, globalization and instant access to information have changed the way business works. Therefore, from now on, the highly competitive and transparent market environment should be prepared quickly to foster the organizations that have superior technical and managerial skills [1] [2].

Quality, process variation reduction, and customer satisfaction have become the top priorities of all organizations. Worldwide, healthcare organizations face many challenges concerning cost, quality, and patients' satisfaction since healthcare is considered a full of discrepancies and complicated process. Therefore, healthcare organizations have been widely adopted systematic innovation approaches to remain up-to-date, competitive, and cost-saving [3].

If an organization is not capable of introducing innovations on an ongoing basis, it risks that it will lag behind and the initiative will be taken over by other entities [4]. Hence, to achieve long-term sustainability, healthcare organizations need continued improvement in a high-disciplined strategy based on reviewing and rectifying processes errors, dedication to customer satisfaction, involving all bodies in the work processes, as appropriate, and other value-adding activities [3]. Therefore, healthcare organizations attempt to apply the Lean Six Sigma (LSS) approach in order to improve the quality of services, increase customer satisfaction level, lower operational costs, increase profits, and achieve success in healthcare services delivery. It should be pointed out, that integrating Six Sigma approach including "Define, Measure, Analyze, Improve, and Control" (DMAIC) with Lean Thinking has multiplied force in the organizational management [5].

Indeed, healthcare organizations have started applying the LSS approach after it was fully established, tested, and confirmed by many firms in the manufacturing sector such as Motorola and General Electric [6]. Lean thinking is one of the most recent conceptions in the manufacturing sector and its transition to being applicable in healthcare organizations is a relatively new phenomenon, since Brandao de Souza, (2009) was the first mentioned reference of application of Lean approach in the healthcare system by Local Government Modernization, the United Kingdom in 2001 [7].

The Lean and Six Sigma approach is a recent concept aims to the continuous improvement of healthcare services, as it has not been conclusively established in the academic research yet. The concept of Lean Six Sigma was incepted because of East-West rivalry and communication about measuring the efficiency of customer satisfaction. Besides, it represents the world's best-experience tested wisdom about using the least to produce the best [8] [9]. Sigma is the 18th letter in the Greek alphabets, and statisticians have used this symbol to denote standard deviation. It is a notion of a management philosophy that goals reducing variation and defects in a process. SS is based on reducing defects by 3.4 opportunities per million is the target level of performance [10]. As well as, Pepper and Spedding (2010) illustrated that the cornerstone of the Lean concept is the re- 
lentless elimination of waste through the calibration of processes and all employees should be involved in process improvement [11].

Rely on previous research Lean and Six Sigma have a complementary relationship with each other in improving the quality of services by reducing costs and wastes, so health care institutions try to apply this methodology to achieve its goals. In 2000, the management of Red Cross Hospital, Netherlands implemented an LSS approach, Based on the LSS approach, the management was able to solve these problems and save $€ 36,000$ per year from unnecessary costs and waste [12]. Taner and Sezen, (2007) debated five case studies about SS methodology implementation in health care: declining avoidable laboratory tests, Refining Magnetic Resonance (MR) image quality, decreasing waiting times before surgery, reducing catheter infections and decreasing the excess length of stay in hospitals [13], additionally Xerox Corp. manufacturing and supply chain operations. In healthcare engineering, DSI laboratories used LSS methodologies to reduce waste and variation in the clinical laboratory. The net result was savings of more than $\$ 400,000$ in the first year. As well as Myocardial Infarction (MI) door-to-balloon process decreased by $58.4 \%$ and developed less than the ACC/AHA standard (90 min). Process cycle efficiency increased from 32.27 to $51.81 \%$, and the average days of hospital stay decreased by 3 days. Such effects helped save NT\$ 4.422 million in the medical resource. This means that LSS not only improved medical quality but also strengthened market competitiveness [14].

Another trend for LSS methodology was implemented at the Health Information Department (HID) of a Medical College hospital in India that describes improvements in the HID cycle time of the process registration was reduced from three to 1.5 minutes. It also informed a $91 \%$ reduction in queue length and a $48 \%$ drop in the percentage of scheduled use of staff for the process [15].

A systemic review was conducted to clarify the role of Lean on emergency crowded and bed hospital shortage and concluded that Lean philosophy is still unknown. Unstandardized but has a significant effect on decreased length of stay and the number of patients left without being seen, reduced costs, and increased patient satisfaction [16]. In addition, Lean and Six Sigma tools can be utilized to promote developments in quality both as a system and as a manner, the researcher focuses on the most important tools. Cavalheiro et al., (2015) clarified how lean six sigma (LSS) was designed as an instrument to arrange for problem-solving and continuous improvement of processes and concluded how it produces an opportunity to classify improvement, as well as the strengths of the staff and the physical therapy service process [17]. Another scope was measured at the physiotherapy domain when Bedi et al., (2015) addressed the evaluation of Musculoskeletal Disorders (MSD) in dentists and the application of the DMAIC technique to improve the ergonomics at dental clinics concluded that using this methodology decreased MSD problems among dentists [18]. Therefore, that Brady and Allen (2012) mention Lean and Six Sigma are paired with a 
relationship with each other [19]. Lean Six Sigma is suitable for the leading continuous improvement technique used by companies in several industries transferred from manufacturing to health care to Information Technology [20] (Table 1).

In the Gaza strip, as an occupied region, many national and international organizations already provide physiotherapies services such as UNRWA, $\mathrm{MOH}$, and other NGOs.

UNRWA is one of the vigorous and major agencies of the United Nations provide healthcare services to Palestinian refugees in the Gaza strip, one of these services is physiotherapy.

LSS has a unique significance in the UNRWA healthcare system since they help sharpen the employee's work and refine his/her character to get him/her prepared to embarrass day-to-day challenges. As a result, an effectively innovative and productive person will be there on both local and international levels. To the best of our knowledge, this paper is the first to identify the impact of Lean Six Sigma practices on physiotherapy service quality at healthcare centers of the UNRWA in the Gaza strip.

\section{Materials and Methods}

\subsection{Sample Size}

A total of 49 physiotherapists working at UNRWA healthcare centers were comprehensively included in this study.

\subsection{Study Period and Sampling Process}

The study was conducted between July 2016 and August 2017. As the physiotherapy services are available in 11 out of 22 UNRWA healthcare centers in the Gaza strip. A pilot study was carried out among 10 physiotherapists selected by convenient sampling from the UNRWA healthcare centers in the Gaza strip in order to test the words of the question, identify any unclear questions, testing the techniques that used to collect data, and measuring the effectiveness of standard invitation to respondents.

Table 1. How lean and (SS) integrate each other.

\begin{tabular}{ll}
\hline \multicolumn{1}{c}{ Lean needs Six Sigma because: } & \multicolumn{1}{c}{ Six sigma needs Lean because } \\
\hline $\begin{array}{l}\text { Lean cannot explain the role needed } \\
\text { to start a project to attain specific results. } \\
\text { It identifies waste. }\end{array}$ & $\begin{array}{l}\text { Six Sigma sub-optimizes processes } \\
\text { decrease process defect. }\end{array}$ \\
$\begin{array}{l}\text { Delivering a collection of tools to know } \\
\text { problems and sources of difference. }\end{array}$ & It improves process speed/cycle time \\
$\begin{array}{l}\text { Lean does not identify the influence } \\
\text { of deviation }\end{array}$ & $\begin{array}{l}\text { It includes methods for continuous } \\
\text { improvement (Kaizen) }\end{array}$ \\
$\begin{array}{l}\text { Lean is not as strong in the measure } \\
\text { and analyze stages of DMAIC }\end{array}$ & $\begin{array}{l}\text { Six Sigma quality is approached faster } \\
\text { if lean eliminate non-value-added steps }\end{array}$
\end{tabular}




\subsection{Study Tools}

A questionnaire was designed to collect information about the impact of Lean Six Sigma practices on the quality of physiotherapy services at healthcare centers of the UNRWA and included three sections: the first section-collected information regarding, socio-demographic information using (five items). The second section used to collect information related to the five Lean Six Sigma Dimensions as follows: Define (seven items), Measure (six items), Analyze (five items), Improve (seven items), Control (six items) (Annex 1). Whereas the third section involved the five aspects to evaluate the quality of physiotherapy services as follows: Tangibility (six items), Reliability (five items), Responsiveness (three items), Assurance (four items), and Empathy (four items). Six professionals in relevant fields judged the questionnaires' validity. The expertise approved that the questionnaire was valid and appropriate enough to measure the purposes that the questionnaire designed for. The internal consistency reliability was employed to measure of how well the items on a test measure the same construct or idea, through measuring the correlation coefficients between each question in one field and the completely filed. The correlation coefficient and $p$-value for each field item were less than 0.05 , so the correlation coefficients of these fields were significant at $\alpha=0.01$ or $\alpha=0.05$, so it can be said that the paragraphs of these fields are consistent and valid to measure what it was set for. Structure validity is the second statistical test used to test the validity of the questionnaire structure by testing the validity of each field and the validity of the whole questionnaire. It measures the correlation coefficient between one filed and all the fields of the questionnaire that has the same level of Likert scale. The significance values were less than 0.01 , so the correlation coefficients of all the fields were significant at $\alpha=0.01$, so it can be said that the fields are valid to be measured what it was set for to achieve the main aim of the study. Cronbach's Coefficient Alpha was used to measure the reliability of the questionnaire between each field and the mean of the whole fields of the questionnaire. The normal range of Cronbach's coefficient alpha value was between 0.0 and +1.0 and the higher values reflect a higher degree of internal consistency. The general reliability for all items was equal to 0.897 . This range is considered high; the result ensures the reliability of the questionnaire.

\subsection{Ethical Consideration}

Written permission was sought and granted by the Field Human Resources Office, UNRWA, Gaza, to carry out the study in the Healthcare centers. Also, the consents were obtained after explaining the purpose of the study and they were not obliged to answer any questions which they did not like and were free to terminate the interview at any given time.

\subsection{Statistical Analysis}

To achieve the research objectives, the Statistical Package for Social Science 
(SPSS) was used to analyze the collected data. Statistical methods were used as follows: Frequencies and Percentile, Alpha-Cronbach Test for measuring the reliability of the items of the questionnaires, Person correlation coefficients for measuring the validity of the items of the questionnaires. Spearman-Brown Coefficient, One-sample $t$-test, Independent samples $t$-test for the difference between two means of independent samples, One way ANOVA test for the difference between means three samples or more, Multiple Regression Model, Stepwise method and Shapiro-will test for the normality test.

\section{Results and Discussion}

The current study showed that the LSS methodology is practiced but its concept is not clear yet. The average of all LSS dimensions means was 4.05 and the means percentage was $81.04 \%$. Moreover, the Lean Six Sigma dimensions are applied in UNWRA healthcare centers in the Gaza Strip at significance level $P<0.05$. The yielded high mean percentages indicate that LSS dimensions were really practiced in the physiotherapy units, however, the LSS approach hasn't completely adopted (Table 2).

Consistent outcomes were found by Sabry (2014) study carried out in Lebanese hospitals in Beirut concluded that 17 out of 19 of Six-Sigma quality program implementation existed and were matched with the quality program applied in the sample [21]. Besides, there are little gaps between the actual ranks of the professionals and the actual ranks of the hospital department managers about the importance degree of critical success factors of the Six-Sigma quality program (CSFs). In addition, the study conducted in Gaza strip banks revealed that they were committed to applying the LSS methodology in Controlling Internal Auditing Quality [22]. Arafeh (2016) found that introducing the Six Sigma DMAIC methodology is a good platform tool to improve the performance of student English language at Elementary School in Amman, Gordan [23].

A consensus between the results of previous studies which stressed the effectiveness of Six Sigma successes in improving the quality of the physical therapy services [16] [17] [24].

According to mentions above all dimensions of LSS are practiced at physiotherapy units noticed that the phase Analyze has the highest ratio (88.1) which

Table 2. Lean six sigma dimensions.

\begin{tabular}{cccccc}
\hline Dimensions & Mean & Standard deviation & Percentage (\%) & $\boldsymbol{t}$-value & $P$-value \\
\hline Analyze & 4.41 & 0.600 & 88.19 & 15.404 & $\mathrm{P}<0.001$ \\
Measure & 4.38 & 0.526 & 87.67 & 17.235 & $\mathrm{P}<0.001$ \\
Define & 4.05 & 0.698 & 81.00 & 9.857 & $\mathrm{P}<0.001$ \\
Improve & 3.99 & 0.784 & 79.80 & 8.281 & $\mathrm{P}<0.001$ \\
Control & 3.50 & 0.766 & 69.92 & 4.248 & $\mathrm{P}<0.001$ \\
Average & 4.05 & 0.591 & 81.04 & 11.664 & $\mathrm{P}<0.001$ \\
\hline
\end{tabular}

*Critical value of $\mathrm{t}$ at $\mathrm{df}$ " 42 " and significance level 0.05 equal 2.02 . 
mean that the processes of collecting, documented then analyzed in good health system information on the other hand the phase control has the lowest ratio (69.9), therefore, the Human resources should reevaluate the performance appraisal.

We explored the association between the LSS dimensions and the quality of physiotherapy services. The overall LSS dimensions showed a significant association with the quality of physiotherapy services (Table 3 ). This finding is consistent with previous studies from different fields, which concluded that there is a relationship between the implementation of the SS approach and maximizing financial benefit. In addition to improving the manufacturing strategy and quality of education at universities [25] [26].

In our study, we identified that all dimensions of (LSS) together have an impact on service quality and showed the most significant dimension is (Improve) as the $p$-value is $<0.05$. Owing to P.T, service which is applied in a unified practical way according to instructions, scientific procedures, and manual therapy. Consistent with Valles et al., (2009) study which concluded that there is an effect of implementation (SS) approach in the manufacturing strategy [26].

On the other side, the study reversed that there are statistically significant differences at $(\alpha \leq 0.05)$ in the responses of the research sample related to the dimensions of Lean Six Sigma due to the personal characteristics of the employees (gender). As $(F=10.295, P$-value $=000)$ that means it's less than 0.05 .

The results indicated that the physiotherapy profession is practiced at UNRWA according to WCPT rules and instructions. No differentiation between males and females (Table 4). Therefore, the work should be in the same methods. Consistent were reported by Dergham and Abdulla (2013) and Jawada (2011) [22] [27].

Our study also, illustrated that no statistically significant differences in the responses of the research sample about lean six sigma dimensions due to the Career level (Table 5). That means clinical instructions and physiotherapy protocol according to World confederation of physical therapy (WCPT) are applied

Table 3. Multiple logistic regression analysis of the association between the Lean Six Sigma dimensions and quality of physiotherapy services.

\begin{tabular}{cccccc}
\hline \multirow{2}{*}{ Dimensions } & \multicolumn{2}{c}{$\begin{array}{c}\text { Unstandardized } \\
\text { Coefficients }\end{array}$} & $\begin{array}{c}\text { Standardized } \\
\text { Coefficients }\end{array}$ & \multirow{2}{*}{$\boldsymbol{t}$-value } & $p$-value \\
\cline { 2 - 4 } & $\mathrm{B}$ & Std. Error & Beta & & \\
\hline Constant & 2.351 & 0.469 & & 5.012 & $\mathrm{P}<0.001$ \\
Define & 0.053 & 0.126 & 0.084 & 0.420 & 0.677 \\
Measure & -0.047 & 0.195 & -0.056 & -0.242 & 0.810 \\
Analyze & 0.108 & 0.144 & 0.147 & 0.752 & 0.457 \\
Improve & 0.322 & 0.133 & 0.571 & 2.413 & 0.021 \\
Control & 0.039 & 0.091 & 0.068 & 0.435 & 0.666 \\
$F=10.295$ & & $P$-Value $=\mathrm{P}<0.001$ & Adjusted $R$-squared $=0.525$
\end{tabular}


Table 4. Lean Six Sigma dimensions according to the gender.

\begin{tabular}{ccccccc}
\hline Dimensions & Gender & $\mathbf{N}$ & Mean & Standard deviation & $\boldsymbol{t}$-value & $P$-value \\
\hline \multirow{2}{*}{ Define } & Male & 22 & 4.10 & 0.704 & 0.515 & 0.609 \\
& Female & 21 & 3.99 & 0.705 & & \\
Measure & Male & 22 & 4.37 & 0.519 & -0.157 & 0.876 \\
& Female & 21 & 4.40 & 0.546 & & \\
Analyze & Male & 22 & 4.41 & 0.646 & -0.002 & 0.998 \\
& Female & 21 & 4.41 & 0.564 & & \\
Improve & Male & 22 & 3.95 & 0.863 & -0.302 & 0.764 \\
& Female & 21 & 4.03 & 0.711 & & \\
Control & Male & 22 & 3.49 & 0.771 & & \\
& Female & 21 & 3.50 & 0.780 & -0.032 & 0.975 \\
& Male & 22 & 4.05 & 0.632 & & \\
\hline
\end{tabular}

Table 5. Lean Six Sigma dimensions according to the professional career levels.

\begin{tabular}{|c|c|c|c|c|c|c|}
\hline Dimensions & Career Level & $\mathbf{N}$ & Mean & Standard deviation & $t$-value & $P$-value \\
\hline \multirow{3}{*}{ Define } & Physiotherapist & 22 & 3.97 & 0.731 & \multirow{3}{*}{-0.724} & \multirow{3}{*}{0.473} \\
\hline & & & & & & \\
\hline & Assistant Physiotherapist & 21 & 4.13 & 0.671 & & \\
\hline \multirow{3}{*}{ Measure } & Physiotherapist & 22 & 4.33 & 0.555 & \multirow{3}{*}{-0.735} & \multirow{3}{*}{0.467} \\
\hline & & & & & & \\
\hline & Assistant Physiotherapist & 21 & 4.44 & 0.501 & & \\
\hline \multirow{3}{*}{ Analyze } & Physiotherapist & 22 & 4.25 & 0.668 & \multirow{3}{*}{-1.775} & \multirow{3}{*}{0.083} \\
\hline & & & & & & \\
\hline & Assistant Physiotherapist & 21 & 4.57 & 0.483 & & \\
\hline \multirow{3}{*}{ Improve } & Physiotherapist & 22 & 3.86 & 0.867 & \multirow{3}{*}{-1.084} & \multirow{3}{*}{0.285} \\
\hline & & & & & & \\
\hline & Assistant Physiotherapist & 21 & 4.12 & 0.683 & & \\
\hline \multirow{3}{*}{ Control } & Physiotherapist & 22 & 3.42 & 0.865 & \multirow{3}{*}{-0.625} & \multirow{3}{*}{0.535} \\
\hline & & & & & & \\
\hline & Assistant Physiotherapist & 21 & 3.57 & 0.659 & & \\
\hline \multirow{3}{*}{ Total } & Physiotherapist & 22 & 3.96 & 0.662 & \multirow{3}{*}{-1.089} & \multirow{3}{*}{0.282} \\
\hline & & & & & & \\
\hline & Assistant Physiotherapist & 21 & 4.15 & 0.504 & & \\
\hline
\end{tabular}

at the same line for both physiotherapy and physiotherapy assistance according regarding the UNRWA Physiotherapy policies, rules, and goals. Consistent with Dergham and Abdulla (2013) which concluded that there are no statistically significant differences at the level of significance $(\alpha \leq 0.05)$ to scientific certificates about internal audit [22]. While disagreement with our result was reported by Jawada (2011) study where a difference was found due to career level as the top management was targeted and little employees have these positions [27]. All 
physiotherapists and assistant physiotherapy are working in the same environment sharing their knowledge, experiences, and practices.

As well as for the differences in the age of the research sample, the study illustrated that there are no differences in the age of the research sample due to age. The study illustrated that physiotherapy services are practiced at the same level for all ages no differences. All employees work under the same circumstances of UNRWA physiotherapy policies, goals, strategies and procedures (Table 6). Consistent with Dergham and Abdulla (2013) which concluded that there were no statistically significant differences between the responses of respondents to age [22].

Additionally the study concluded the results for all (Service Quality) dimensions showed that the average mean equal 4.26 and the weight mean equal $85.14 \%$ which is greater than "60\%" and the value of $t$ test equal 18.674 which is greater than the critical value which is equal 2.02 and the p-value equal 0.000 which is less than 0.05 . That means Service Quality in UNRWA health centers-Gaza Strip is practiced at physiotherapy units. Clarifying the levels of quality according to SS levels, actually it lies between the second and third levels according to SS levels which was stated in (Table 7).

Table 6. Lean six sigma dimensions according to the participants age groups.

\begin{tabular}{|c|c|c|c|c|c|c|}
\hline Dimensions & Source & Sum of Squares & $\mathrm{df}$ & Mean Square & $t$-value & $P$-value \\
\hline \multirow{3}{*}{ Define } & Between Groups & 1.452 & 3 & 0.484 & & \\
\hline & Within Groups & 19.033 & 39 & 0.488 & 0.992 & 0.407 \\
\hline & Total & 20.485 & 42 & & & \\
\hline \multirow{3}{*}{ Measure } & Between Groups & 1.637 & 3 & 0.546 & & \\
\hline & Within Groups & 10.004 & 39 & 0.257 & 2.127 & 0.112 \\
\hline & Total & 11.641 & 42 & & & \\
\hline \multirow{3}{*}{ Analyze } & Between Groups & 1.224 & 3 & 0.408 & & \\
\hline & Within Groups & 13.892 & 39 & 0.356 & 1.145 & 0.343 \\
\hline & Total & 15.116 & 42 & & & \\
\hline \multirow{3}{*}{ Improve } & Between Groups & 1.392 & 3 & 0.464 & & \\
\hline & Within Groups & 24.420 & 39 & 0.626 & 0.741 & 0.534 \\
\hline & Total & 25.812 & 42 & & & \\
\hline \multirow{3}{*}{ Control } & Between Groups & 0.897 & 3 & 0.299 & & \\
\hline & Within Groups & 23.741 & 39 & 0.609 & 0.491 & 0.690 \\
\hline & Total & 24.638 & 42 & & & \\
\hline \multirow{3}{*}{ Total } & Between Groups & 1.072 & 3 & 0.357 & & \\
\hline & Within Groups & 13.613 & 39 & 0.349 & 1.024 & 0.393 \\
\hline & Total & 14.685 & 42 & & & \\
\hline
\end{tabular}

*Critical value of $\mathrm{F}$ at $\mathrm{df}$ "3.39" and significance level 0.05 equal 2.85 . 
Table 7. Quality of physiotherapy services according to the career level.

\begin{tabular}{cccccccc}
\hline No. & Items & Mean & $\begin{array}{c}\text { standard } \\
\text { deviation }\end{array}$ & $\begin{array}{c}\text { Weight } \\
\text { mean }\end{array}$ & t-value & P-value & Rank \\
\hline $\mathbf{4}$ & Assurance & 4.47 & 0.588 & 89.42 & 16.401 & 0.000 & 1 \\
$\mathbf{5}$ & Empathy & 4.42 & 0.505 & 88.49 & 18.513 & 0.000 & 2 \\
$\mathbf{2}$ & Reliability & 4.42 & 0.612 & 88.37 & 15.193 & 0.000 & 3 \\
$\mathbf{3}$ & Responsiveness & 4.30 & 0.654 & 86.05 & 13.060 & 0.000 & 4 \\
$\mathbf{1}$ & Tangibles & 3.84 & 0.508 & 76.90 & 10.899 & 0.000 & 5 \\
& All items & 4.26 & 0.441 & 85.14 & 18.674 & 0.000 & \\
\hline
\end{tabular}

${ }^{*}$ Critical value of $t$ at $\mathrm{df}$ " 42 " and significance level 0.05 equal 2.02 .

\section{Limitations of the Study}

The researcher's place of work has given her an advantage for fewer limitations. However, there have been some limitations:

- Lack of resources and materials about the study of concern.

- The crowding at physiotherapy units also may make the patients in stress, as they want to go home quickly.

- Long period electricity cut off has proven great limitation since the patients flow is arranged according to the appointment system, so the patients rearrange their work and home affairs according to schedule of electricity, which led the stations to be more congestion and put the staff and patients in more stress.

\section{Conclusion}

Our study indicated that employees practice the LSS but its concept is not clear yet as approach. The average of all LSS dimensions means was 4.05 and the means percentage of applications was $81.04 \%$. Moreover, the Lean Six Sigma dimensions are applied in UNWRA healthcare centers in the Gaza Strip at significance level $P<0.05$. The yielded high mean percentages indicate that LSS dimensions were really practiced in the physiotherapy units; however, the LSS approach has not completely adopted. Therefore, the study recommends that the application of Lean Six Sigma should be adopted as a practice and approach in the physiotherapy units in the UNRWA healthcare centers in the Gaza strip. Moreover, physiotherapists training and reward according to a needs assessment to implement Lean Six Sigma successfully is highly recommended.

\section{Conflicts of Interest}

The authors declare no conflicts of interest regarding the publication of this paper.

\section{References}

[1] Simons, N. (2010) Leveraging Generational Work Styles to Meet Business Objec- 
tives. Information Management, 44, 28.

[2] Crane, A., Matten, D., Glozer, S. and Spence, L. (2019) Business Ethics: Managing Corporate Citizenship and Sustainability in the Age of Globalization. Fifth Edition, Oxford University Press, Oxford.

[3] Graban, M. (2018) Lean Hospitals: Improving Quality, Patient Safety, and Employee Engagement. Third Edition, Productivity Press, New York. https://doi.org/10.4324/9781315380827

[4] Hana, U. (2013) Competitive Advantage Achievement through Innovation and Knowledge. Journal of Competitiveness, 5, 82-96.

https://doi.org/10.7441/joc.2013.01.06

[5] Laureani, A., Antony, J. and Douglas, A. (2010) Lean Six Sigma in a Call Centre: A Case Study. International Journal of Productivity and Performance Management, 59, 757-768. https://doi.org/10.1108/17410401011089454

[6] Burgess, N. and Radnor, Z. (2013) Evaluating Lean in Healthcare. International Journal of Health Care Quality Assurance, 26, 220-235.

https://doi.org/10.1108/09526861311311418

[7] Trends, L. (2009) Approaches in Lean Healthcare. Leadership in Health Services, 22, 121-139. https://doi.org/10.1108/17511870910953788

[8] Dahlgaard-Park, S.M. and Bendell, T. (2006) A Review and Comparison of Six Sigma and the Lean Organisations. The TQM Magazine, 18, 255-262. https://doi.org/10.1108/09544780610659989

[9] Antony, J., Rodgers, B. and Gijo, E.V. (2016) Can Lean Six Sigma Make UK Public Sector Organisations More Efficient and Effective? International Journal of Productivity and Performance Management, 65, 995-1002. https://doi.org/10.1108/IJPPM-03-2016-0069

[10] Gupta, V., Acharya, P. and Patwardhan, M. (2012) Monitoring Quality Goals through Lean Six-Sigma Insures Competitiveness. International Journal of Productivity and Performance Management, 61, 194-203.

https://doi.org/10.1108/17410401211194680

[11] Pepper, M.P. and Spedding, T.A. (2010) The Evolution of Lean Six Sigma. International Journal of Quality \& Reliability Management, 27, 138-155. https://doi.org/10.1108/02656711011014276

[12] Ahmed, S., Manaf, N.H. and Islam, R. (2013) Effects of Lean Six Sigma Application in Healthcare Services: A Literature Review. Reviews on Environmental Health, 28, 189-194. https://doi.org/10.1515/reveh-2013-0015

[13] Taner, M.T., Sezen, B. and Antony, J. (2007) An Overview of Six Sigma Applications in Healthcare Industry. International Journal of Health Care Quality Assurance, 20, 329-340. https://doi.org/10.1108/09526860710754398

[14] Yeh, H.L., Lin, C.S., Su, C.T. and Wang, P.C. (2011) Applying Lean Six Sigma to Improve Healthcare: An Empirical Study. African Journal of Business Management, 5, 12356-12370. https://doi.org/10.5897/AJBM11.1654

[15] Bhat, S., Gijo, E.V. and Jnanesh, N.A. (2014) Application of Lean Six Sigma Methodology in the Registration Process of a Hospital. International Journal of Productivity and Performance Management, 63, 613-643. https://doi.org/10.1108/IJPPM-11-2013-0191

[16] Bucci, S., De Belvis, A.G., Marventano, S., De Leva, A.C., Tanzariello, M., Specchia, M.L., Ricciardi, W. and Franceschi, F. (2016) Emergency Department Crowding and Hospital Bed Shortage: Is Lean a Smart Answer? A Systematic Review. European Review for Medical and Pharmacological Sciences, 20, 4209-4219. 
[17] Cavalheiro, L.V., Eid, R.A.C., Talerman, C., Prado, C.D., Gobbi, F.C.M. and Andreoli, P.B.D.A. (2015) Design of an Instrument to Measure the Quality of Care in Physical Therapy. Einstein (São Paulo), 13, 260-268. https://doi.org/10.1590/S1679-45082015GS3248

[18] Bedi, H.S., Moon, N.J., Bhatia, V., Sidhu, G.K. and Khan, N. (2015) Evaluation of Musculoskeletal Disorders in Dentists and Application of DMAIC Technique to Improve the Ergonomics at Dental Clinics and Meta-Analysis of Literature. Journal of Clinical and Diagnostic Research, 9, ZC01. https://doi.org/10.7860/JCDR/2015/14041.6126

[19] Brady, J.E. and Allen, T.T. (2006) Six Sigma Literature: A Review and Agenda for Future Research. Quality and Reliability Engineering International, 22, 335-367. https://doi.org/10.1002/qre.769

[20] Bevan, H., Westwood, N., Crowe, R. and O’Connor, M. (2007) Lean Six Sigma: Some Basic Concepts. NHS Institute for Innovation and Improvement.

https://www.england.nhs.uk/improvement-hub/wp-content/uploads/sites/44/2017/ 11/Lean-Six-Sigma-Some-Basic-Concepts.pdf

[21] Sabry, A. (2014) Factors Critical to the Success of Six-Sigma Quality Program and Their Influence on Performance Indicators in Some of Lebanese Hospitals. Arab Economic and Business Journal, 9, 93-114. https://doi.org/10.1016/j.aebj.2014.07.001

[22] Dergham, M. and Abdulla, H. (2013) Compliance with Six Sigma Methodology in Controlling Internal Auditing Quality: An Empirical Study on the Banks Operating in the Gaza Strip. Journal of the Islamic University for Economic and Administrative Studies, 21, 57-100.

https://iugspace.iugaza.edu.ps/bitstream/handle/20.500.12358/24231/370-1144-1-P B.pdf? sequence $=1$ \&isAllowed $=y$

[23] Arafeh, M. (2016) Leveraging Six Sigma Tools and Methodology to Improve Student English Language Performance at Elementary School. American Journal of Operations Research, 6, 720-726.

[24] Gharibi, F., Tabrizi, J., Oskouei, M.E. and AsghariJafarabadi, M. (2014) Effective Interventions on Service Quality Improvement in a Physiotherapy Clinic. Health Promotion Perspectives, 4, 61.

[25] Wasiloff, C. (2018) Maximizing Financial Benefit of Lean Six Sigma Projects through Optimized Selection Criteria. Engineering Management, Information, and Systems Research Theses and Dissertations, Southern Methodist University, Dallas. https://pdfs.semanticscholar.org/39c0/3c4555581911655b2670f6ecd08ec1e27ff2.pdf

[26] Valles, A., Sanchez, J., Noriega, S. and Nuñez, B.G. (2009) Implementation of Six Sigma in a Manufacturing Process: A Case Study. International Journal of Industrial Engineering, 16, 171-181.

[27] Jawada, S. (2011) Feasibility of Application of Six Sigma and Its Role in Improving the Quality of Health Services in the Government Hospitals in Gaza Strip from the Perspective of Senior Management. M.Sc. Theses, Islamic University of Gaza, Faculty of Economics and Administrative Sciences, Gaza.

https://iugspace.iugaza.edu.ps/bitstream/handle/20.500.12358/17557/file_1.pdf?sequ ence $=1$ \&isAllowed $=\mathrm{y}$ 


\section{Annexes}

\section{Annex one: Questionnaire}

1) Socio-demographic information

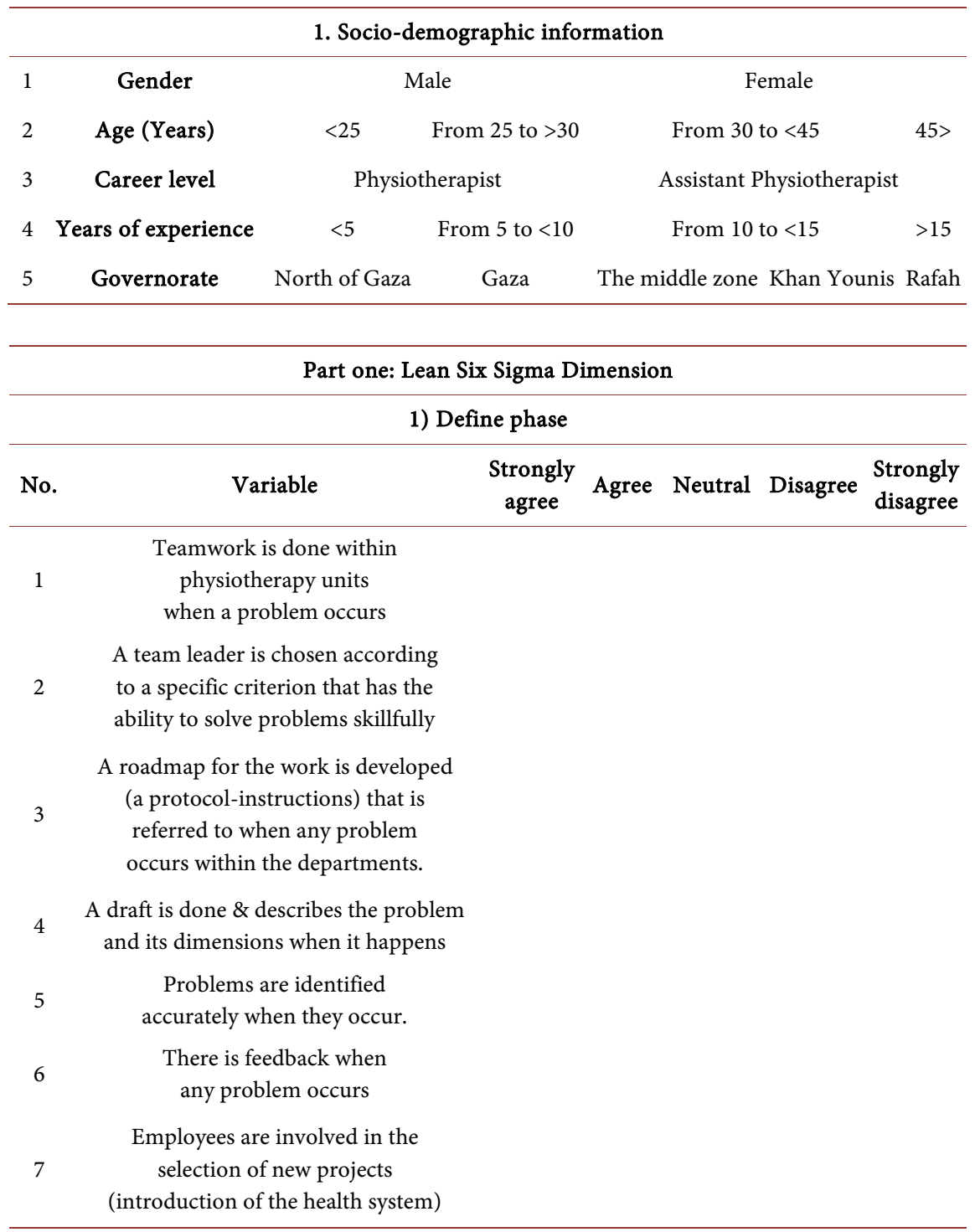

2) Measure phase

\begin{tabular}{|c|c|c|c|c|c|c|}
\hline No. & Variable & $\begin{array}{c}\text { Strongly } \\
\text { agree }\end{array}$ & Agree & Neutral & Disagree & $\begin{array}{l}\text { Strongly } \\
\text { disagree }\end{array}$ \\
\hline 1 & $\begin{array}{l}\text { Data is collected regularly and } \\
\text { easily within physiotherapy units }\end{array}$ & & & & & \\
\hline 2 & $\begin{array}{l}\text { The facts and figures are checked } \\
\text { when any problem occurs in } \\
\text { physiotherapy units correctly }\end{array}$ & & & & & \\
\hline 3 & $\begin{array}{c}\text { Inputs are measured for } \\
\text { intra-departmental processes } \\
\text { (such as reception of new patients) }\end{array}$ & & & & & \\
\hline
\end{tabular}




\section{Continued}

Outputs are measured for intra-units

processes (such as patients' satisfaction

with the service provided/patient

complaint/liability determination)

Patient data is recorded and their

files are monitored on a daily basis

A preliminary report is drawn up

on the problems faced by workers

and patients after challenging

them and trying to solve them

3) Analyze phase

No. $\begin{gathered}\text { Paragraph } \\ \text { the data are analyzed in an } \\ \text { appropriate statistical manner } \\ \text { when any problem occurs } \\ \text { within physiotherapy units }\end{gathered}$
$\begin{aligned} & \text { Patient and file data are } \\ & \text { documented correctly }\end{aligned}$
$3 \quad$ Data is easily referenced when needed
disagree

4) Improve phase

\begin{tabular}{|c|c|c|c|c|c|c|}
\hline No. & Paragraph & $\begin{array}{l}\text { Strongly } \\
\text { agree }\end{array}$ & Agree & Neutral & Disagree & $\begin{array}{l}\text { Strongly } \\
\text { disagree }\end{array}$ \\
\hline 1 & $\begin{array}{l}\text { Alternatives are developed } \\
\text { after identifying the root } \\
\text { causes of the problems }\end{array}$ & & & & & \\
\hline 2 & $\begin{array}{l}\text { Regular feedback of the } \\
\text { workflow is taken }\end{array}$ & & & & & \\
\hline 3 & $\begin{array}{l}\text { The protocol of physiotherapy is } \\
\text { referred to when any problem occurs }\end{array}$ & & & & & \\
\hline 4 & Employees are involved at all levels & & & & & \\
\hline 5 & $\begin{array}{l}\text { The protocol is amended based } \\
\text { on a deeper understanding of } \\
\text { the problems that may occur }\end{array}$ & & & & & \\
\hline 6 & $\begin{array}{l}\text { Work within a structured } \\
\text { and always clear framework }\end{array}$ & & & & & \\
\hline 7 & $\begin{array}{l}\text { Employees accept any change } \\
\text { in work methods easily }\end{array}$ & & & & & \\
\hline
\end{tabular}


N. M. A. Sharikh et al.

5) Control phase

\begin{tabular}{|c|c|c|c|c|c|c|}
\hline No. & Paragraph & $\begin{array}{l}\text { Strongly } \\
\text { agree }\end{array}$ & Agree & Neutral & Disagree & $\begin{array}{l}\text { Strongly } \\
\text { disagree }\end{array}$ \\
\hline 1 & $\begin{array}{l}\text { Employees are evaluated } \\
\text { continuously by the supervisors }\end{array}$ & & & & & \\
\hline 2 & $\begin{array}{l}\text { Solutions are developed for } \\
\text { problems that may occur } \\
\text { after the evaluation process }\end{array}$ & & & & & \\
\hline 3 & $\begin{array}{l}\text { The staff are evaluated } \\
\text { within specific criteria }\end{array}$ & & & & & \\
\hline 4 & $\begin{array}{l}\text { Employees Provide management } \\
\text { with the outputs of processes that } \\
\text { reflect the needs of patients }\end{array}$ & & & & & \\
\hline 5 & $\begin{array}{l}\text { The performance of the } \\
\text { staff is improved based } \\
\text { on the evaluation outputs }\end{array}$ & & & & & \\
\hline 6 & $\begin{array}{l}\text { Performance is linked to } \\
\text { physical or moral incentives }\end{array}$ & & & & & \\
\hline
\end{tabular}

\section{Part two: Service Quality Dimensions}

\begin{tabular}{|c|c|c|c|c|c|c|}
\hline \multicolumn{7}{|c|}{ 1) Tangibility } \\
\hline No. & paragraph & $\begin{array}{c}\text { strongly } \\
\text { agree }\end{array}$ & Agree & Neutral & Disagree & $\begin{array}{l}\text { Strongly } \\
\text { disagree }\end{array}$ \\
\hline
\end{tabular}

The units provides the material needs and within the available resources

2 Quality goals are known to employees

3

I think the cost of quality is low and achievable

I believe that quality can be achieved without the use of advanced equipment and technology

There is a waiting room for patients and offices of workers within each section

The staff in the units have an elegant appearance and are fully formalized

\section{2) Reliability}

units are committed to their

1 promises to patients in the provision of therapeutic services provided

The staff members sympathize with

2 the patients when they complain about the level of service provided

The patients develop their

3 confidence in the workers and in the quality of service provided to them 


\section{Continued}

The staff in the PT units are interested

4 in recording information about patients and their health condition

Patients get service easily

\section{3) Responsiveness}

The patients are informed about the times of the sessions and the coordination of their dates

The service is provided immediately to patients

The workers respond quickly to the requests of patients despite their busy

\section{4) Assurance}

The patients trust the employees with great confidence

2 reassures the patient that he is in good hands

The employees treat the patients with elegance Employees have merit, courtesy and credibility

\section{5) Empathy}

units are concerned with the personal care of patients

The needs of patients (appointments-days) Appropriate for them)

Working hours are compatible with patients' times

The best service is provided to patients during the treatment period 